\title{
Deteksi spora Bacillus anthracis
}

\author{
MLE Parwanto \\ Departemen Biologi, Fakultas Kedokteran Universitas Trisakti, Indonesia \\ Email: edyparwanto@trisakti.ac.id
}

Bacillus anthracis ditemukan dalam 2 bentuk yaitu bentuk vegetatif dan bentuk spora. Pada prinsipnya, faktor virulensi anthrax karena produksi kapsul dan eksotoksin selama fase vegetatif. ${ }^{(1)}$ Spora $B$. anthracis berupa endospora dan merupakan agen infeksi yang tahan terhadap panas, kering, zat kimia maupun iradiasi serta dapat bertahan dalam waktu yang lama. ${ }^{(2)}$ Infeksi spora $B$. anthracis mengakibatkan penyakit anthrax antara lain pada usus, kulit dan paru-paru. Penyakit anthrax termasuk penyakit zoonosis yang berpotensi mematikan terhadap manusia. ${ }^{(3)}$

Bentuk vegetatif maupun bentuk spora $B$. anthracis dapat dideteksi dengan cara yang berbeda. Ada beberapa cara untuk mendiagnosis bentuk vegetatif $B$. anthracis dalam diri seseorang, antara lain menggunakan antibodi Ig $G$ serum anthrax. (4) Selain itu, pengujian bentuk vegetatif dapat dilakukan dengan mengisolasi $B$. anthracis dari sumbernya, kemudian isolat diuji secara morfologis, biokimiawi, maupun uji secara genetik. Dewasa ini telah digunakan Tetracore RedLine Alert_Test yaitu test cepat untuk deteksi isolat B. anthracis. ${ }^{(5)}$

Deteksi spora $B$. anthracis menjadi penting karena antara lain dapat dijadikan sebagai agen infeksi. Untuk mendeteksi spora terlebih dahulu dilakukan kultur terhadap isolat $B$. anthracis pada medium agar serum, selanjutnya dikultur pada medium agar darah domba untuk menstimulasi pembentukan kapsul. Spora B. anthracis yang terbentuk kemudian dideteksi dengan berbagai cara. Visualisasi spora $B$. anthracis menggunakan mikroskop dapat dilakukan setelah dicat menurut metode Schaefer dan Fultton. ${ }^{(6)}$

Bagian terluar spora $B$. anthracis merupakan dinding spora. Lapisan terluar dinding spora $B$. anthracis disebut exosporium yang tersusun atas beberapa jenis protein. Salah satu jenis protein tersebut yaitu Bacillus collagen-like protein of anthracis (BclA) atau anthrose. ${ }^{(7)}$ Berbagai cara dilakukan untuk mendeteksi spora $B$. anthracis antara lain menggunakan poly chain reaction (PCR), spectrometry, flow cytometry dan mikroskop elektron. Kami juga mengembangkan cara sederhana untuk mendeteksi spora $B$. anthracis menggunakan metode presipitasi dan immunochromatography. Kami mengkultur isolat $B$. anthracis pada medium agar darah (SigmaAldrich) untuk menginduksi sporulasi. Spora yang terbentuk kemudian dicat dengan malachite green dan tampil berwarna hijau. Deteksi anthrosa dilakukan dengan 2 tahap yaitu presipitasi dan elektroforesis. Reaksi presipitasi terhadap anthrosa menggunakan goat antibody anti anthrosa (GA3). GA3 diperoleh dengan cara purifikasi dari serum darah kambing yang sebelumnya divaksinasi dengan vaksin anthrax. Hasil reaksi presipitasi tersebut menghasilkan warna putih silver. Electroforesis menggunakan marker protein digunakan untuk memvisualisasikan anthrosa. Berat molekul anthrosa memperlihatkan \pm 148 $\mathrm{kDa}{ }^{(6)}$

\section{REFERENSI}

1. Scorpio A, Chabot DJ, Day WA, O'brien DK, Vietri NJ, Itoh Y, et al. Poly-gamma-glutamate capsule-degrading enzyme treatment enhances phagocytosis and killing of encapsulated Bacillus anthracis. Antimicrob Agents Chemother. 2007;51(1):215-22. DOI: 10.1128/AAC.0070606. Available from: https://www.ncbi.nlm.nih.gov/ pubmed/17074794

2. Tamborrini M, Holzer M, Seeberger PH, Schürch N, Pluschke G. Anthrax spore detection by a luminex assay based on monoclonal antibodies that 
recognize anthrose-containing oligosaccharides. Clin Vaccine Immunol. 2010;17:1446-51. doi: 10.1128/CVI.00205-10. Epub 2010 Jul 21. Available from: https://www.ncbi.nlm.nih.gov/ pubmed/20660139

3. Saraswathi SV, Padmavathy J, Mamatha B, Bindu HSN, Vijayalakshmi S. A Sin of Biotechnology, Bioterrorism-Anthrax. Int $\mathrm{J}$ PharmTech Res. 2010;2:2044-7. Available from: https://www. researchgate.net/publication/289691120 A sin of biotechnology bioterrorism - anthrax

4. Redhono D, Dirgahayu P. Anthrax Seroprevalence in Central Java, Indonesia. Indonesian Journal of Medicine (2016), 1(2): 129-135. Available from: https://doi.org/10.26911/theijmed.2016.01.02.07

5. Pillai SP, Prentice KW, Ramage JG et al. Rapid Presumptive Identification of Bacillus anthracis Isolates Using the Tetracore RedLine Alert Test. Health Security 2019, 17(4):334-343. DOI: $10.1089 / \mathrm{hs} .2019 .0038$. Available from: https://www.liebertpub.com/doi/abs/10.1089/ hs.2019.0038

6. Parwanto MLE, Pakpahan A, Edy HJ. Simple detection of Bacillus anthracis spores by precipitation method with goat antibody anti anthrosa. Int J Res Med Sci 2016;4:4319-25. DOI: $\quad$ http://dx.doi.org/10.18203/2320-6012. ijrms20163286.

7. Daubenspeck JM, Zeng H, Chen $\mathrm{P}$ et al. Novel oligosaccharide side-chains of the collagen-like region of $\mathrm{BclA}$, the major glycoprotein of Bacillus anthracis. J Biol Chem. 2004;279:30945-53. DOI: 10.1074/jbc.M401613200. Available from: https:// www.ncbi.nlm.nih.gov/pubmed/15152001 